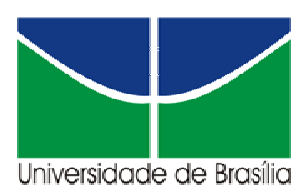

$\mathbf{P}$

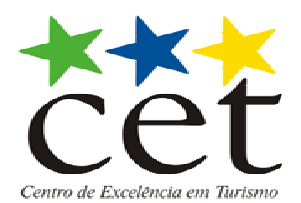

UNIVERSIDADE DE BRASÍLIA

CENTRO DE EXCELÊNCIA EM TURISMO

\title{
PARQUE ECOLÓGICO E DE USO MÚLTIPLO OLHOS D’ÁGUA: ANÁLISE DOCUMENTAL E SITUACIONAL
}

\author{
Renata Bizzo Hirata
}

Monografia apresentada ao

Centro de Excelência em Turismo da Universidade de Brasília como requisito parcial para a obtenção do certificado de Especialista em Ecoturismo

Brasília, DF, Outubro de 2004 

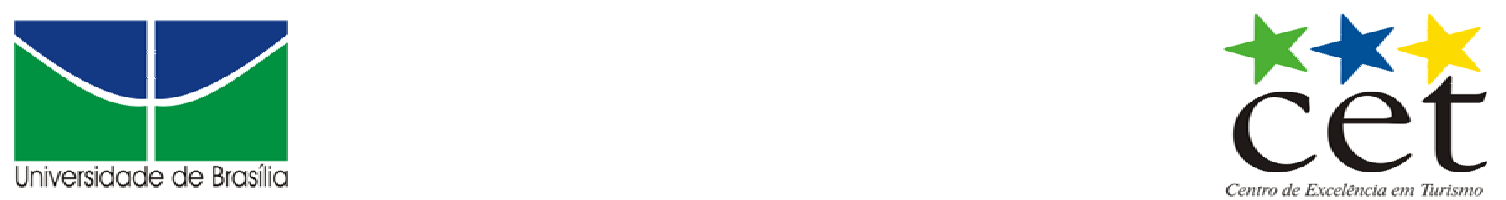

UNIVERSIDADE DE BRASÍLIA

Centro de Excelência em Turismo

Curso de Especialização em Ecoturismo

PARQUE ECOLÓGICO E DE USO MÚLTIPLO OLHOS D’ÁGUA: ANÁLISE DOCUMENTAL E SITUACIONAL

Renata Bizzo Hirata

Banca Examinadora

Profa . Laís Mourão

Brasília, DF, 04 de Outubro de 2004 
Hirata, Renata Bizzo

PARQUE ECOLÓGICO E DE USO MÚLTIPLO OLHOS D’ÁGUA: ANÁLISE DOCUMENTAL E SITUACIONAL / Renata Bizzo Hirata

$46 f$

Especialização em Ecoturismo - Universidade de Brasília. Centro de Excelência em Turismo. Brasília, 2004

Área de concentração: Ecoturismo

1. Ecoturismo 2. Parques de Brasília 3. PARQUE ECOLÓGICO E DE USO MÚLTIPLO OLHOS D’ÁGUA: ANÁLISE DOCUMENTAL E SITUACIONAL 
RENATA BIZZO HIRATA

\section{PARQUE ECOLÓGICO E DE USO MÚLTIPLO OLHOS D'ÁGUA: ANÁLISE DOCUMENTAL E SITUACIONAL}

Comissão Avaliadora

Professor

Professor

Brasília, DF, 04 de outubro de 2004 


\section{AGRADECIMENTOS}

Agradeço aos meus pais pelas condições que me proporcionaram. À minha irmã, por ter me ouvido e me ajudado nos momentos difíceis.

À todos os meus colegas de sala, o meu obrigada por terem muitas vezes me acolhido quando não podia desenvolver adequadamente as minhas obrigações.

Obrigada pela atenção que o pessoal da secretaria me ofereceu, em especial à Graça pela atenção e preocupação quando os problemas surgiram. Obrigada também ao Pedro, que sempre foi tão atencioso e gentil.

Por fim, obrigada à todos do CET pela acolhida a todos os estudantes. 
Parece-me que o prêmio mais alto possível para qualquer trabalho humano não é o que se recebe por ele, mas o que se torna através dele.

Brock Bell 


\section{SUMÁRIO}

$\begin{array}{ll}\text { 1. INTRODUÇÃO } & 09\end{array}$

2. O BIOMA CERRADO 12

$\begin{array}{ll}\text { 2.1. Desenvolvimento Sustentável } & 13\end{array}$

3. OS PARQUES DE BRASÍLIA E O ECOTURISMO 15

4. METODOLOGIA 23

4.1. Histórico do Parque 26

5. RESULTADOS E DISCUSSÕES 28

6. CONCLUSÃO 42

7. BIBLIOGRAFIA 46 


\section{LISTA DE FIGURAS}

Figura 01: Cercamento do parque visto da entrada principal 29

Figura 02: Trilha em bloquete intertravado 30

Figura 03: Trilha de pavimentação asfáltica com 3 mil metros de extensão $\quad 30$

Figura 04: Vista do Centro de Educação Ambiental 31

Figura 05: Lagoa do Sapo $\quad 32$

Figura 06: Vista das lixeiras para coleta seletiva 33

Figura 07: Modelo de lixeira existente ao longo da trilha 34

Figura 08: Modelo de lixeira existente na entrada do parque 34

Figura 09: Placa existente para a localização dos atrativos turísticos do parque 35

Figura 10: Sinalização contra atear fogo 36

Figura 11: Placa danificada por ação de vandalismo 36

Figura 12: Placa informativa na entrada do parque $\quad 37$

Figura 13: Aviso de alerta ao longo da trilha. 37

Figura 14: Espécies exóticas próximas as nascentes 38

Figura 15: Presença de bananeiras próximo a Lagoa dos Sapos 39

Figura 16: Parque Infantil $\quad 40$

$\begin{array}{ll}\text { Figura 17: Equipamento de ginástica } & 40\end{array}$

Figura 18: Bosque dos Eucaliptos $\quad 41$ 


\section{INTRODUÇÃO}

O Bioma Cerrado compreende $1 / 4$ do país, a sua matéria prima está relacionada com suas características bióticas e abióticas e suas perspectivas de uso são inúmeras.

Devido à essas características e a sua diversidade, as pressões por que passa são inúmeras. Essas pressões vão desde o uso e ocupação do sola, até as extrações de minérios, madeiras etc.

O Distrito Federal, encontra-se inserido neste bioma, sofrendo com estas pressões.

O fator que mais fez acelerar o desmatamento do cerrado nesta região foi rápido processo de expansão humana ocorrido desde a construção.

Com o passar dos anos, a população começou a demonstrar preocupação com questões relacionadas com o meio ambiente. Com isso, começou a pressionar os órgãos competentes para que áreas de lazer fossem criadas mas que valorizassem as questões ambientais. 
O Governo do Distrito Federal e seus órgãos relacionados começaram a investir na criação de Parques Ecológicos tanto em Brasília como nas cidades satélites.

Mas não basta somente a criar o empreendimento, se não houver uma administração responsável, este empreendimento tende ao colapso.

O presente trabalho teve como objetivo, analisar documentos existentes que serviram para aprovar a criação do Parque Ecológico e de Uso Múltiplo Olhos D’água, analisando a intenção dos órgãos responsáveis que era de que esse parque viesse a ser utilizado para atividades recreativas da comunidade local. 


\section{O BIOMA CERRADO}

O cerrado é considerado o segundo maior bioma brasileiro, ocupando cerca de 2 milhões de quilômetros quadrados, quase 25\% do território brasileiro. Estima-se que existam mais de 40\% de espécies de árvores endêmicas. Com relação a diversidade de vertebrados, Câmara \& Santos (2002) apontam ter aproximadamente 161 espécies de mamíferos, 837 espécies de aves, sendo 3\% endêmicas; cerca de 120 espécies de répteis (20\% endêmicos), e 150 espécies de anfíbios com $30 \%$ de endemismo.

O Bioma Cerrado apresenta diversas formações vegetais denominadas fitofisionomias que podem ser de 3 tipos: florestais, savânicas e campestres, além de diversos subtipos. Foram identificadas cerca de 6400 espécies vegetais com diversos potenciais de uso como alimentar, forrageiro, tanífero, artesanal, ornamental, corticeiro, melífero, oleaginoso, entre outros (RIBEIRO et al, 2003).

O cerrado possui 204 milhões de hectares, sendo 127 milhões aráveis, correspondendo a $62 \%$ do total. Dessas terras aráveis, 49 milhões (38\%) 
estão ocupadas por pastagens cultivadas, 10 milhões com culturas anuais $(7,8 \%)$ e 2 milhões com culturas perenes e florestais (1,5\%). Dos 10 milhões de hectares plantados com culturas temporárias, 5600 são de soja, o que representa $56 \%$ do total plantado (RIBEIRO et al, 2003).

A pressão urbana e o rápido estabelecimento de atividades agrícolas vêm reduzindo rapidamente a biodiversidade destes ecossistemas. Em meados dos anos 60, as atividades agrícolas eram restritas, direcionadas a agricultura de subsistência, principalmente à produção extensiva de gado de corte. Após esse período, devido ao crescimento urbano e industrial do Sudeste, forçou a agricultura para o Centro-oeste. Atualmente, esta região contribui com $70 \%$ da produção de carne bovina do país, sendo também importante centro de produção de grãos (PIVELLO, 2004).

Desta forma, torna-se de extrema importância estudos de impacto ambiental com o intuito de que se tenha minimizado os efeitos devastadores dessa ocupação desordenada e da agropecuária. 


\subsection{O Desenvolvimento Sustentável}

A partir das últimas décadas, pode-se dizer que a questão ambiental tornou-se preocupação mundial. Com o aumento da complexidade dos problemas ambientais, passou-se a exigir cada vez mais medidas pontuais que buscassem resolver ou minimizar os problemas a partir de seus efeitos, ignorando ou desconhecendo suas causas.

Em 1987 a Comissão Mundial de Meio Ambiente e Desenvolvimento das Nações Unidas, apresentou um relatório (Relatório Brundland), que constava o conceito de desenvolvimento sustentável. Desenvolvimento sustentável foi definido como um desenvolvimento que satisfaz as necessidades do presente sem comprometer a capacidade das gerações futuras satisfazerem as suas (MUNHOZ, 2003).

Dessa forma, desenvolvimento sustentável é definido como aquele capaz de melhorar a qualidade de vida humana dentro dos limites da capacidade suporte dos ecossistemas. O termo capacidade suporte encontra-se definido, segundo Faria \& Carneiro (2001) como sendo "o tamanho máximo estável de uma 
população, determinado pela quantidade de recursos disponíveis e pela demanda mínima individual".

O conceito de sustentabilidade pode ter enfoque sobre três aspectos:

a) uso sustentável, ocorre quando os seres humanos utilizam os recursos renováveis, permitindo dessa forma, que processos naturais de reposição ocorram podendo o sistema renovar-se indefinidamente; b) crescimento sustentável, a questão é se o crescimento econômico leva ou não em consideração a limitação de recursos, sem ocorrer a degradação do ambiente; e c) desenvolvimento sustentável, é a garantia da preservação de ambientes em alto risco de sobrevivência(FARIA \& CARNEIRO, 2001, p.15).

Um desenvolvimento sustentável autêntico para um mundo contemporâneo, implicaria em garantir a preservação de ambientes com alto risco de sobrevivência. Deve procurar envolver quatro setores: a comunidade, os órgãos governamentais, sistema educacional e o setor produtivo. A atuação conjunta desses quatro setores é de extrema importância para que um programa de desenvolvimento sustentável comece a mostrar resultados (FARIA \& CARNEIRO, 2001, p.22). O sucesso das ações dependerá em grande parte da influência da opinião pública, do comportamento das pessoas e de suas decisões individuais.

Para que se tenha um desenvolvimento sustentável no bioma do cerrado, será necessário considerar as peculiaridades ambientais existentes, as econômicas e sociais, propondo políticas de conservação e utilização de sua biodiversidade. 


\section{OS PARQUES DE BRASÍLIA E O ECOTURISMO}

O conceito de parque começou a ser reconhecido como um meio pelo qual se podia garantir oportunidades de recreação ao ar livre no campo. O parque de Yellowstone, nos EUA, foi implantado para prevenir a exploração do meio ambiente e da vida selvagem, para recreação e, finalmente, como meio para o estudo científico (FENNELL, 2002, p.84).

Os parques servem a uma grande variedade de propósitos, enfrentando numerosas pressões. O processo de urbanização das cidades levou ao surgimento de locais áridos, implantados sobre regiões previamente desflorestadas.

Segundo dados do IPDF apud Ganem \& Leal (2000, p.11), o Distrito Federal tem uma superfície de $5.783 \mathrm{~km}^{2}$, dos quais $90 \%$ originalmente eram cobertos de vegetação de cerrado. Aproximadamente $42 \%$ do território do DF compreende unidades de conservação federais e distritais.

O Distrito Federal enfrenta sérios problemas ambientais, os quais estão relacionados com o desmatamento, poluição hídrica e a erosão do solo. 
Esses problemas são decorrentes, principalmente do acelerado processo de expansão urbana ocorrido desde a construção de Brasília. Ainda segundo dados do IPDF apud Ganem \& Leal (2000, p.11), 93\% da população do DF reside em áreas urbanas e parte dos sete por cento restantes residem em condomínios situados na zona rural.

Os parques foram criados e implementados com o objetivo de minimizar os problemas ambientais citados acima, tornando possível, desta forma, combinar a conservação dos ecossistemas naturais com a disponibilização dessas áreas para a população. Normalmente, são regiões com ocorrência de córregos, lagos e/ou vegetação abundante que constitui um atrativo para a população.

No ano de 2000, segundo dados de Ganem \& Leal (2000, p.12), existiam no Distrito Federal, 44 parques criados sob diferentes denominações ecológico, vivencial, ecológico e vivencial, recreativo, vivencial e recreativo, recreativo e ecológico, urbano, urbano e vivencial ou simplesmente sob a denominação de parque.

A expansão das áreas destinadas a parques no DF ocorreu de forma acelerada e desordenada, sem nenhum estudo prévio. Até 1990, não existia nenhuma norma legal que estabelecia-se os objetivos e as características dos parques e os critérios para sua criação.

De acordo com a Lei Complementar n²65/99, são estabelecidas duas categorias de parques - os ecológicos e os de uso múltiplo. Parques de uso múltiplo devem situar-se dentro de núcleos urbanos ou contíguos a eles, em áreas de fácil acesso cobertas por vegetação, seja ela nativa ou exótica e visam ainda: 
- conservar as áreas verdes de grande beleza cênica;

- recuperar áreas degradadas e promover a sua revegetação;

estimular a educação ambiental e as atividades de lazer em contato harmônico com a natureza.

Já os parques ecológicos, devem conter pelo menos trinta por cento da área com cobertura de vegetação nativa e têm como objetivo:

- conservar amostras dos ecossistemas naturais;

- proteger paisagens naturais de notável beleza cênica;

- proteger e recuperar recursos hídricos, edáficos e genéticos;

- recuperar áreas degradadas e promover sua revegetação com espécies nativas ;

- estimular o desenvolvimento de atividades de pesquisa, estudos e monitoramento ambiental;

- estimular o desenvolvimento da educação ambiental e das atividades de lazer em contato harmônico com a natureza (GANEM \& LEAL, 2000, p.81).

Em 14 de março de 2000, através do Decreto $n^{\circ} 21.063$ foi criada a Comissão Permanente de Parques Ecológicos e de Uso Múltiplo do DF, que competia:

“I - assessorar o Governador do Distrito Federal na implantação dos parques e propor a criação de estrutura administrativa para sua gestão;

II - definir critérios para a política de implantação e utilização dos parques, bem como adequação da legislação pertinente às finalidades propostas; 
III - propor alternativas que garantam a sustentabilidade econômica e ambiental dos parques e promover o trabalho integrado entre os órgãos do complexo administrativo do Governo do Distrito Federal e a sociedade civil; IV - definir prioridades na implantação dos parques existentes, em função das peculiaridades locais" (GANEM \& LEAL, 2000, p.13).

Praticamente todos os parques criados, apresentavam cobertura vegetal nativa ou com maciços arbóreos de espécies exóticas, em partes de suas áreas ou em toda a sua extensão. Vale ressaltar que a criação dos parques não foi precedida de estudos básicos de sítios, nem se baseou em diretrizes de zoneamento que apontassem a adequação das áreas.

Em 9 dos 44 parques criados, existiam áreas degradadas muito antes de sua criação, e que ainda não foram recuperadas, ou que ainda sofrem com retirada de areia, cascalho e/ou terra (GANEM \& LEAL, 2000, p.84). Além de comprometerem a paisagem local, essas áreas estão sujeitas à erosão, dificultando a sua revegetação e causando o assoreamento dos córregos. A presença do lixo também é um problema generalizado dos parques. Presente em todas as unidades é oriundo da deposição irregular, da presença de usuários ou da passagem de transeuntes.

Um fator importante é que 13 desses parques contavam com a presença de nascentes em seu interior, em estado de conservação variável, tanto em relação à vegetação circundante quanto à qualidade de suas águas (GANEM \& LEAL, 2000, p.85). Muitos deles são utilizados, principalmente como área de banho, entretanto, as atividades de lazer são desenvolvidas informalmente, sem infra-estrutura adequada ou projetos educativos. 
Dezenove parques contavam com trilhas que poderiam ser aproveitadas para caminhadas, contemplação, observação ecológica e outras atividades que sejam compatíveis com a área. Essas trilhas eram pouco ou nada utilizadas pela população, devido, em muitos casos, a problemas de segurança, além de serem difíceis para idosos e crianças (GANEM \& LEAL, 2000, p.90).

Quanto ao planejamento de uso, de acordo com a Lei Complementar n²65/99, cada parque deveria ter um plano de manejo que viesse a disciplinar, com base no zoneamento, o seu uso e sua ocupação. Somente dois parques contavam, quando da publicação dos trabalhos de Ganem \& Leal (2000, p.91), de um plano de manejo elaborado: os Parques Ecológicos Ezechias Heringer e Burle Marx. A maioria dos parques não tinha estudos técnicos necessários para embasar os planos de manejo.

Como foi citado anteriormente, os parques foram criados e implementados com o intuito de estarem minimizando os problemas ambientais que vinham ocorrendo no DF tornando possível, desta forma, a combinação da conservação dos ecossistemas naturais com a disponibilização dessas áreas para a população.

No Distrito Federal, os parques aparecem como alternativas capazes de atender a dois importantes objetivos - o primeiro é de se tornarem viveiros permanentes de espécies raras e o segundo é de servir como fórum para a realização da Educação Ambiental (SEMARH, 2003, 13p.).

Devido à demanda da população por espaços naturais, cada vez mais vem crescendo a atividade ecoturística, tanto em Brasília como nas demais cidades que contam com atrativos naturais. 
Segundo dados da WWF apud Neves (2002, p.08) o "Brasil é um dos países mais ricos do mundo em termos ambientai: possui $8.511 .996 \mathrm{~km}^{2}$, cerca de 1/3 das florestas tropicais remanescentes e o maior sistema fluvial do planeta. 0 Brasil possui ainda a parte mais extensa do maior complexo de terras inundáveis do mundo (o pantanal), a savana com a mais rica diversidade biológica (o cerrado) e mais mangues de que qualquer outro país. Essa vasta paisagem abriga uma variedade gigantesca de fauna e flora (esta representa $22 \%$ da flora mundial)".

O ecoturismo cresceu devido a insatisfação com as formas convencionais de turismo que, ignoraram os elementos sociais e ecológicos de regiões em países estrangeiros ou não. O século $X X$ foi o período de evolução do ecoturismo, naquele baseado na vida selvagem africana e, para outros, nos empreendimentos de turismo na natureza da metade do século XIX (FENNELL, 2002, p.43).

Ainda não existe um consenso quanto à definição do ecoturismo. Uma coisa é comum a todas elas: o ecoturismo é utilizado como uma ferramenta para a conservação e o desenvolvimento sustentável.

O ecoturismo ou, como muitos o chamam turismo ecológico, não só pode ser um elemento promotor da conservação dos recursos naturais, como pode estar contribuindo para o financiamento de programas de conservação ambiental e o desenvolvimento de uma comunidade. Trata-se de uma alternativa que, possibilita e viabiliza a participação individual do cidadão interessado em fazer algo para proteger o meio ambiente (NEVES, 2002, p.02).

Para Goodwin apud Fennell (2002, p.46) o ecoturismo é "o turismo na natureza de baixo impacto, que contribui à manutenção de espécies e habitats 
diretamente, por meio de uma contribuição à conservação e/ou indiretamente produzindo rendimentos para as comunidades locais, para que elas valorizem e, portanto, protejam suas áreas herdadas de vida selvagem como fonte de renda".

Para a rede WWF apud Salvati (2002, p.30) o ecoturismo pode ser descrito como "turismo realizado em áreas naturais, determinado e controlado pelas comunidades locais gerando benefícios para elas e para áreas relevantes para a conservação da biodiversidade".

No conceito brasileiro, o ecoturismo encontra-se sustentado em três eixos: a sustentabilidade, a educação do visitante e os benefícios às comunidades locais. A sustentabilidade refere-se ao ambiente natural, considerando-se a sua viabilidade econômica. As bases de sustentação dos negócios de ecoturismo são os ambientes natural e cultural, como recursos atrativos. Se esta base não se encontrar conservada, não haverá o interesse de visitação. Por isso, a sustentabilidade envolve a utilização criteriosa desses recursos.

Quanto à questão da educação do visitante é vista no sentido de que o turismo e o ecoturismo são sempre informativos e educacionais. O ecoturismo tem a função de proporcionar ao visitante uma conscientização da importância de se preservar a natureza, assim como a história e a cultura local. No ecoturismo, com a prática da educação ambiental é possível contribuir para que o visitante modifique seu comportamento no cotidiano e que o mesmo adote posturas diferentes no seu ambiente.

O intuito maior do desenvolvimento sócio-econômico sustentável é que se tenha um envolvimento das comunidades da região com o turismo seja na 
recepção das pessoas ou até mesmo na participação para se elaborar atividades comerciais locais.

No ecoturismo, verifica-se uma estreita relação homem-natureza. O impacto do pode ser identificado a partir dos custos potenciais como, a degradação do meio ambiente, injustiças e instabilidades econômicas, mudanças sócioculturais negativas; e dos benefícios potenciais como a geração de receitas para as áreas protegidas, criação de empregos e promoção da educação ambiental (BOO, 1995 apud FARIA \& CARNEIRO, 2001, p.71). 


\section{METODOLOGIA}

O trabalho foi realizado no Parque Ecológico e de Uso Múltiplo Olhos d’Água, localizado na cidade de Brasília - DF.

Foi realizada uma visita no Centro de Documentação da Secretaria de Meio Ambiente e Recursos Hídricos - SEMARH, com o objetivo de se fazer um levantamento de todos os documentos existentes deste parque. Além disso, foi realizada uma visita no CEDOC do jornal Correio Brasiliense com o intuito de que fossem obtidas reportagens antigas deste parque.

Ainda, foram realizadas visitas ao parque onde foram tiradas fotos que serviram para ilustrar este trabalho.

Em um dos momentos das visitas, o Administrador Regional foi procurado para uma entrevista, mas aceitou somente se fosse uma conversa informal, que serviu para levantar alguns problemas ao longo do trabalho. 


\subsection{Histórico do Parque}

O Parque Ecológico Olhos d'Água foi criado através do decreto $\mathrm{n}^{\circ}$ 15.900 de 17 de setembro de 1994 onde o Governador sancionou sua criação.

De acordo com o Art. $2^{\circ}$, o Parque tem por objetivo:

I - preservação das nascentes, olhos dágua, córrego e da lagoa existente;

II - preservação da mata de galeria e da fauna associada a esse tipo de vegetação, bem como sua recuperação nas áreas que se encontram degradadas; III - proporcionar o desenvolvimento de programas de observação e educação ambiental, além de pesquisas sobre os ecossistemas locais;

IV - proporcionar à população lazer cultural que vise principalmente o desenvolvimento de atividades que levem em conta a conservação do meio ambiente".

A idéia para a criação desse parque é de que ele poderia servir como modelo para a implantação de outros parques no Distrito Federal, proporcionando a população, novos espaços de lazer e convívio harmônico com a natureza. 
A criação do Parque se deu em função da mobilização dos moradores das SQN 415/416 e entorno que, por esta área apresentar características de topografia acentuadas várias nascentes e olhos d'água, mata ciliar, área de cerrado e um pequeno lago, demandava uma maior proteção ambiental (IEMA, 1994; GUIA DO PARQUE ECOLÓGICO OLHOS D’ÁGUA, 1998, p.18). Desta forma, o Parque nasceu a partir do anseio da comunidade próxima, ao mesmo tempo, fazendo parte de uma estratégia de conservação do meio ambiente permitindo a otimização da qualidade de vida local. Sendo seu processo de criação participativo, comunidade - governo, as ações para sua implantação incentivaram a co-gestão e o envolvimento amplo da comunidade.

Este parque encontra-se inserido numa área urbana de 21 hectares situado no Plano Piloto, estende-se ao longo da SQN 413/414 apresentando 3 acessos: pela via L1 norte, comercial da quadra 413 e pelo lado residencial da 414 norte.

O Parque Ecológico Olhos D’água encontra-se entre quadras residenciais da Asa Norte, próximo a instituições de ensino básico público e particular, e próximo também da estação biológica da UnB. Visitantes em sua maioria são constituídos por jovens e idosos que vão desfrutar do ambiente para caminhadas diárias, visitas educativas das diversas escolas do DF e visitas realizadas pela Universidade de Brasília para estudos científicos (PARQUE OLHOS D’AGUA, 1998, p.02).

O parque tem por finalidade a preservação de nascentes, preservação e recuperação da Lagoa, preservação e recuperação da mata ciliar, proteção da bacia do Lago Paranoá, desenvolvimento de programas de 
observação ecológica e pesquisas sobre ecossistemas locais, criação de condições para a população usufruir o local numa preservação ambiental e desenvolvimento de atividades voltadas para a educação ambiental.

Através do Decreto $\mathrm{n}^{\circ}$ 21.784, de 05 de novembro de 2000, o Secretário de Meio Ambiente e Recursos Hídricos do Distrito Federal, transforma o parque em Parque Ecológico e de Uso Múltiplo Olhos Dágua.

O solo do Parque é classificado em cambissolo (solo pouco desenvolvido devido ao relevo mais acidentado das superfícies nas quais se desenvolve), apresentando uma variação topográfica suave acima de $1000 \mathrm{~m}$.

Por apresentar-se dentro dos limites do Distrito Federal apresenta tipos climáticos: Tropical de Savana e Tropical de Altitude, com dois períodos bem definidos: estação seca que vai de maio a outubro e estação chuvosa, compreendendo os meses de novembro a abril.

Antes de sua criação, a área abrangida pelo parque foi alvo de invasões, o que causou as degradações presenciadas atualmente. Algumas formas de vegetação encontradas hoje são: Campo Cerrado, Mata Mesofítica, Mata de Galeria. As principais espécies vegetais encontradas pelo Parque são: pau-jacaré (Piptadenia gonoacantha), embaúba (Cecropia pachystachya), copaíba (Copaifera langsdorffi), barbatimão (Stryphnodendron adstringen), pau-terra (Qualca grandiflora), angico (Anadenanthera macrocarpa), faveira (Dimorphandra mollis).

Com relação à fauna do Parque, podem ser encontrados pequenos mamíferos como gambá, preá; aves; répteis; anfíbios e peixes. Morcegos podem 
ser encontrados nas matas e borda da mata pode ser encontrado ainda em frestas dos prédios localizados próximo ao Parque. Estes animais desempenham importante papel ecológico, pois são importantes dispersores de sementes e tem um importante papel no controle de populações de insetos.

A avifauna que pode ser encontrada é abundante isso porque no Parque Olhos Dágua a área de Mata Mesofítica apresenta grande cobertura vegetal e com isso oferece abrigo a estas aves. Outra explicação para esse fenômeno é de que o Parque fica situado próximo ao lago Paranoá, o qual oferece grandes depósitos alimentares.

O Parque é cortado por um córrego cuja cabeceira situa-se na SQN 212/213. O talvegue do córrego encontra-se bem definido geomorfologicamente na SQN 413. A segunda cabeceira evidenciada pela Mata Ciliar que se apresenta degradada em alguns trechos, localiza-se na SQN 414 e SCLN 414/415 


\section{RESULTADOS E DISCUSSÕES}

Com o objetivo de que o parque atraísse o interesse para a visitação, era necessário de que ele oferecesse segurança e equipamentos apropriados para atividades de lazer, as áreas degradadas recuperadas, projetos paisagísticos implantados, os córregos despoluídos e o acesso interno melhorado (GANEM \& LEAL, 2000, p. 99).

Atualmente o Parque Olhos D’água conta com um Batalhão da Polícia Florestal, este com um efetivo de apenas 4 homens, que por mecanismo de revezamento, realizam o policiamento de todo o parque. Neste mesmo local encontra-se, o escritório da administração do parque.

De acordo com o Plano de Zoneamento e Manejo (SEMARH, 1998), todas as edificações implantadas no parque deveriam ser projetadas de eucalipto com no máximo dois pavimentos. O que pode ser visto neste local, são construções antigas em alvenaria, contrariando a regulamentação citada acima.

Ainda segundo este Plano de Zoneamento e Manejo, ao longo da via L2, deveria ter sido plantadas mudas de copaíbas com o intuito de servirem como 
barreira acústica desta avenida. No local foi realizado um cercamento com grade de metal, que permanece até os dias de hoje.

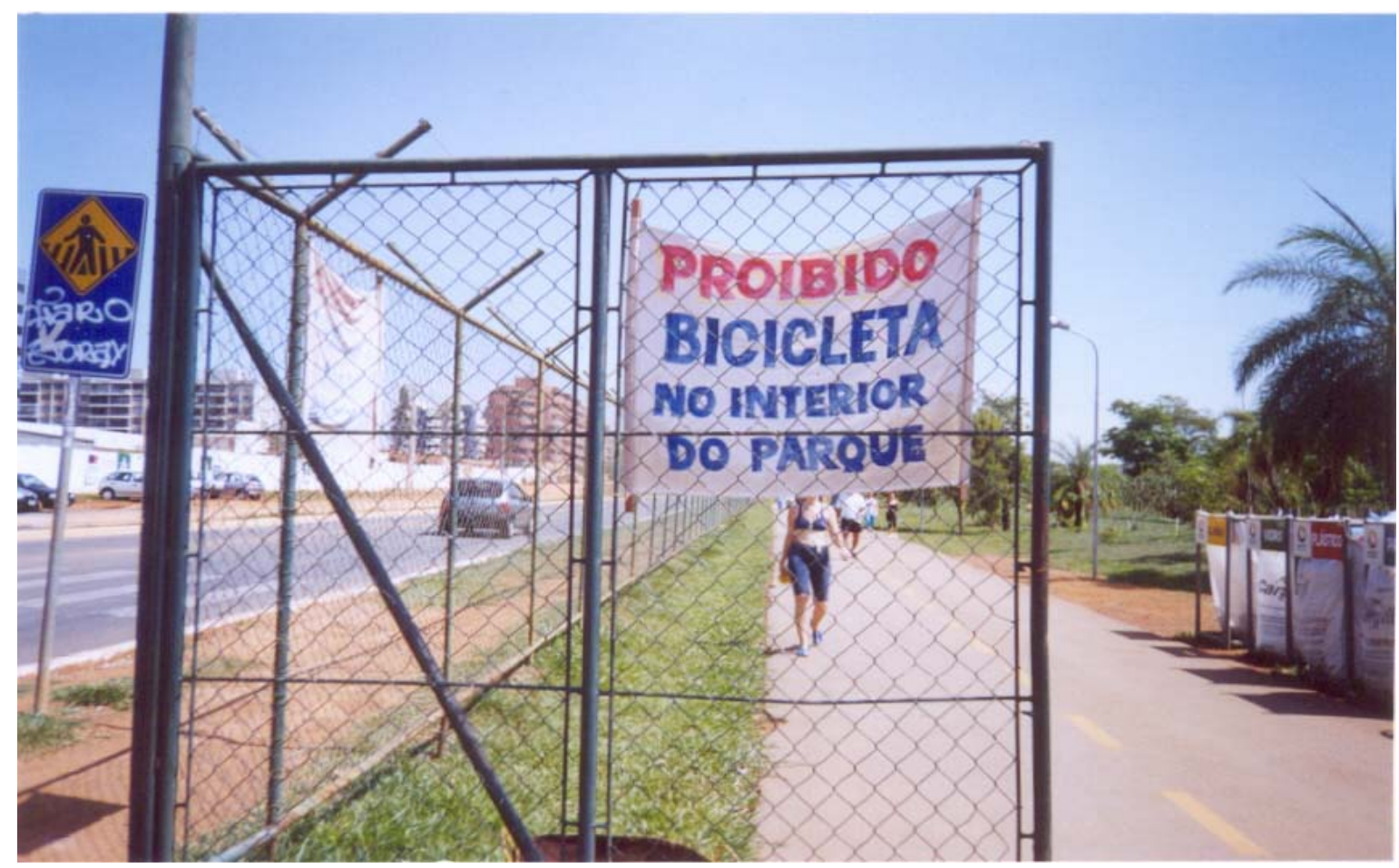

Figura 01: Cercamento do parque visto da entrada principal.

No local deveria haver trilhas naturais de chão batido, com placas de sinalização educativas, em pontos estratégicos, assim como implantar trilhas para deficientes visuais e físicos (Plano de Zoneamento e Manejo,1998, p. 10). No local não são vistas estas trilhas naturais e não ocorre um sistema adequado de sinalização.

O parque conta com trilhas em bloquetes intertravados que permitem a permeabilidade da água no solo, e de pavimentação asfáltica com 3 mil metros de extensão, objetivando atender a Lei Distrital $n^{\circ} 2867$ de 29 de janeiro de 2001, referente ao acesso aos portadores de deficiências físicas. 


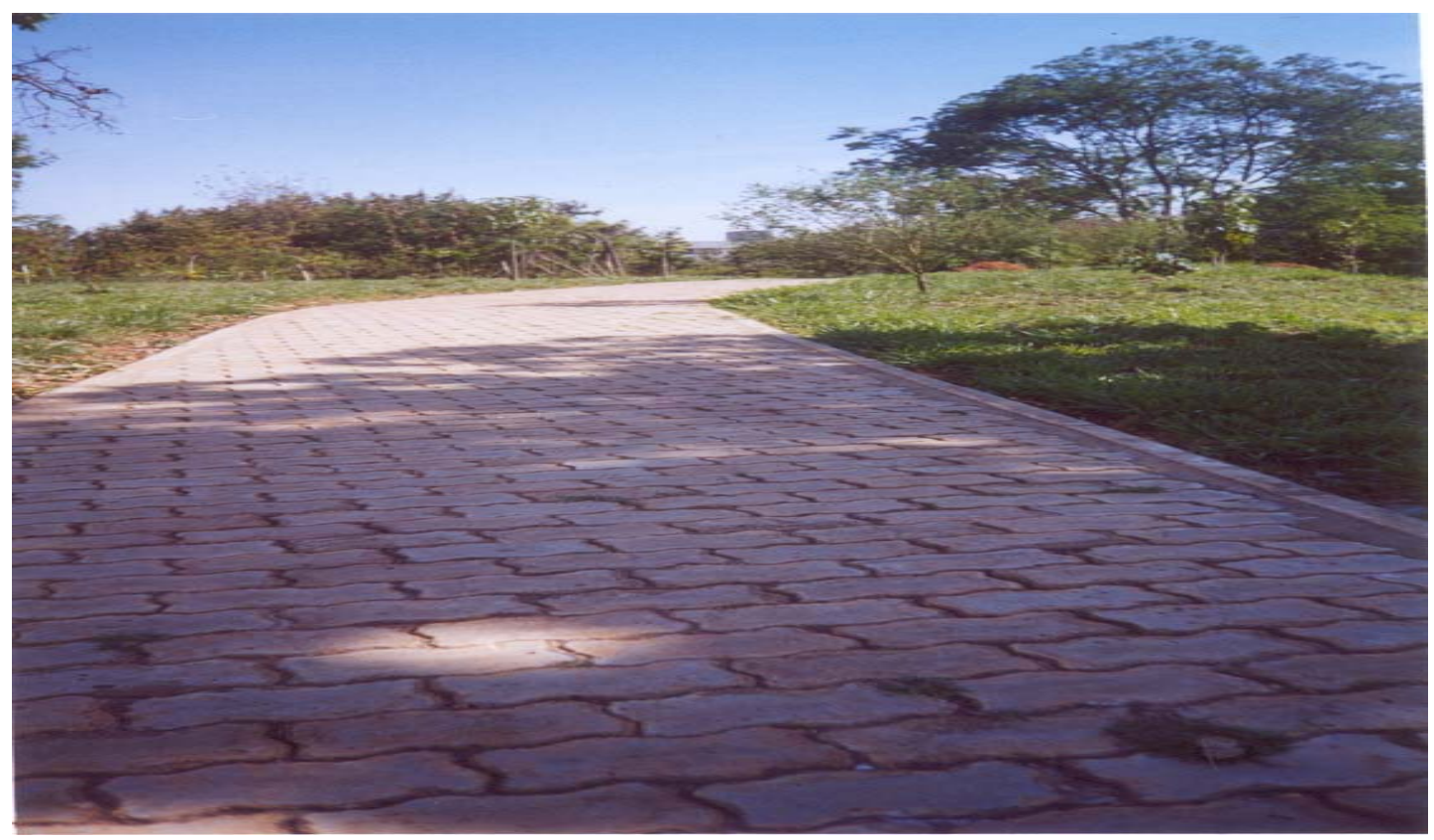

Figura 02: Trilha em bloquete intertravado

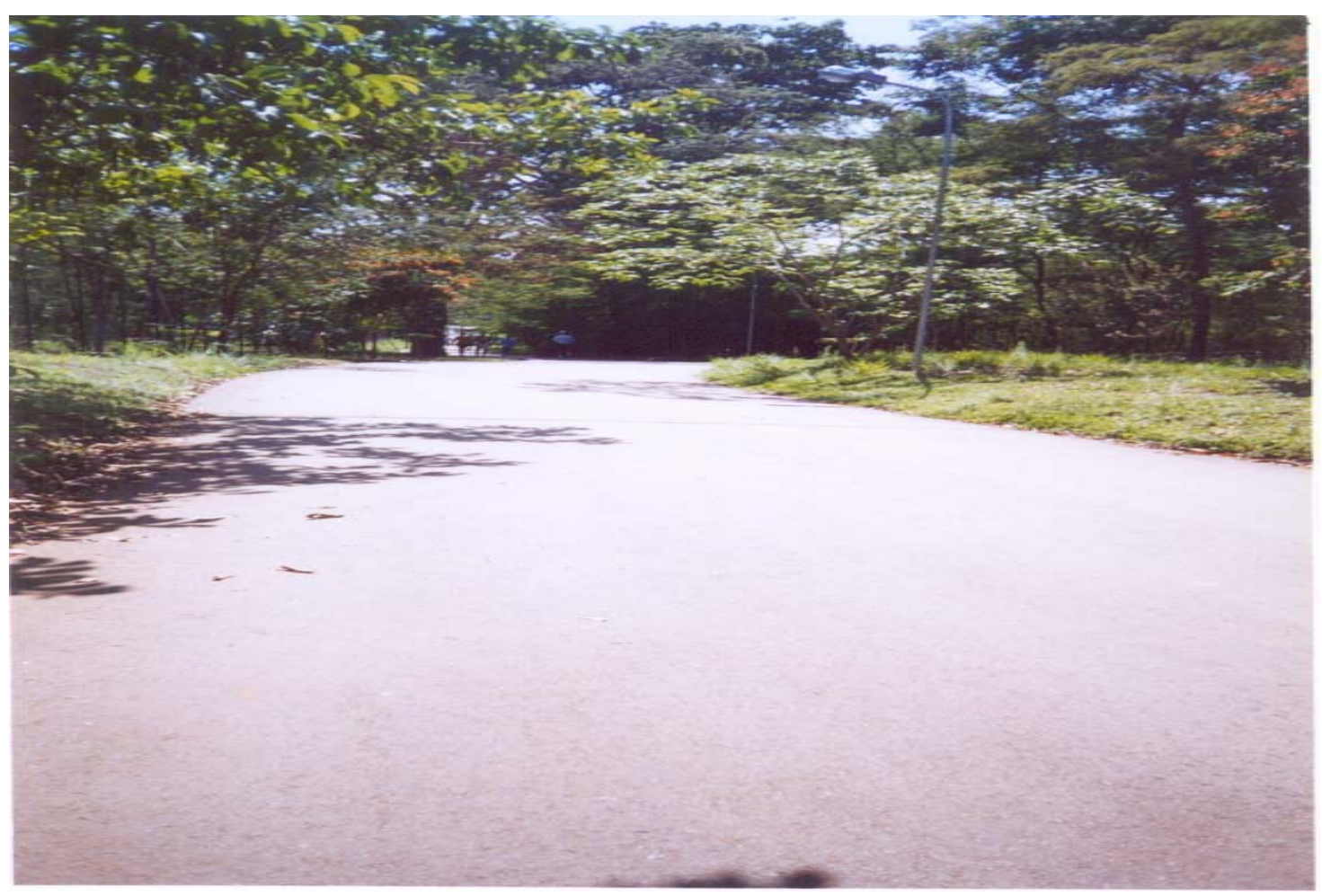

Figura 03: Trilha de pavimentação asfáltica com 3 mil metros de extensão 
Foram instalados 2 hidrantes nas extremidades da área que serviriam como suporte ao corpo de bombeiros. Ainda construiu-se 2 duchas frias para que os freqüentadores pudessem se refrescar, além de um Centro de Educação Ambiental, com estrutura para palestras, exposições e teatro, além de contarem com pias e armários para atender ao público visitante (Plano de Zoneamento e Manejo,1998, p. 19).

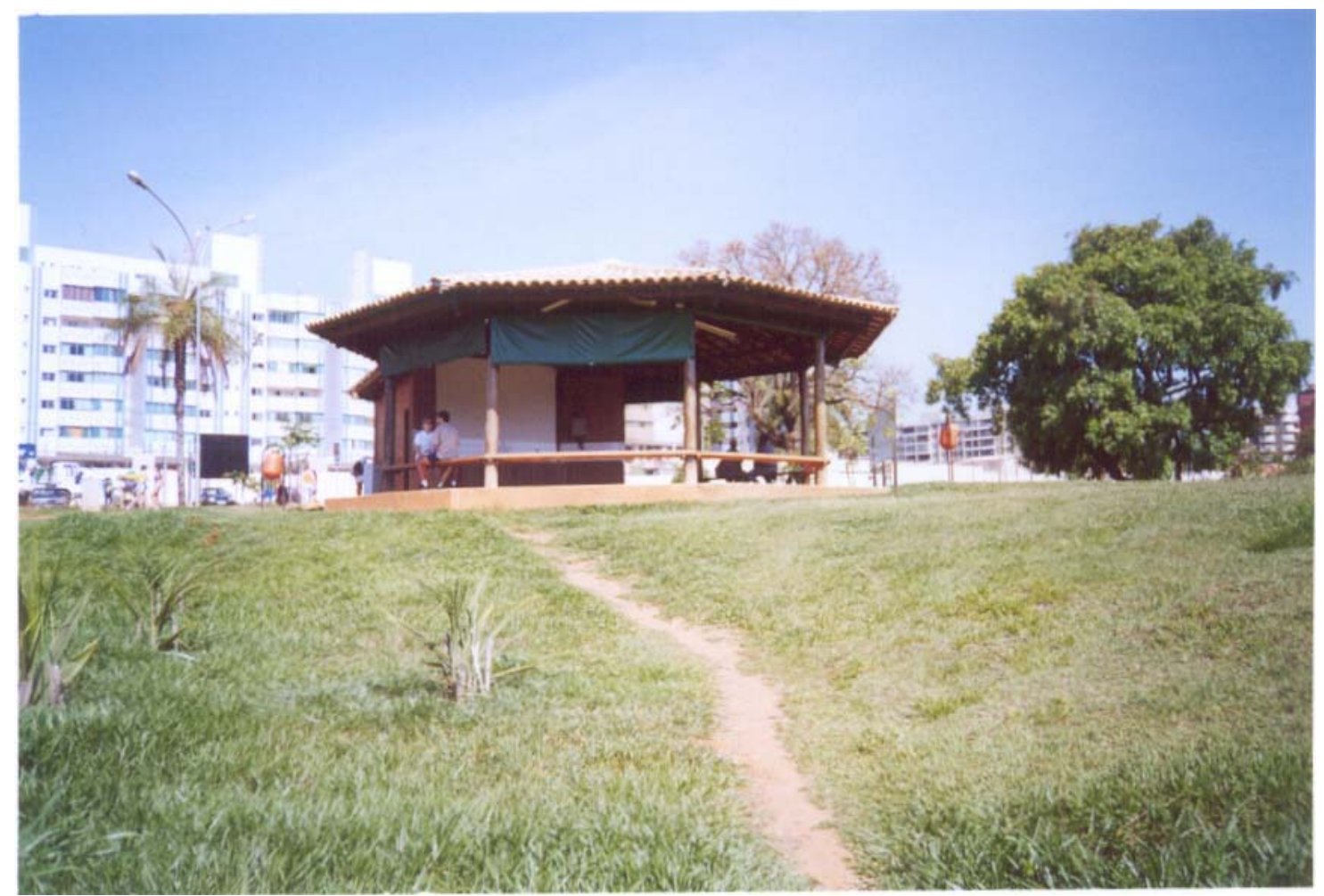

Figura 04: Vista do Centro de Educação Ambiental

No início da implantação do parque foram construídas 3 pontes, uma sobre a Lagoa do Sapo com 93 metros de extensão e outras duas sobre o talvegue para dar passagem aos dois lados do mesmo. Segundo laudo da CAESB(Companhia de Água e Esgoto de Brasília), em 02 de fevereiro de 1994, a 
água que abastece o parque encontrava-se contaminada. De acordo com o administrador, ainda hoje não foi feito novo exame nas águas que abastecem o parque, mas o que pode ser percebido é que o mesmo ainda se encontra contaminado.

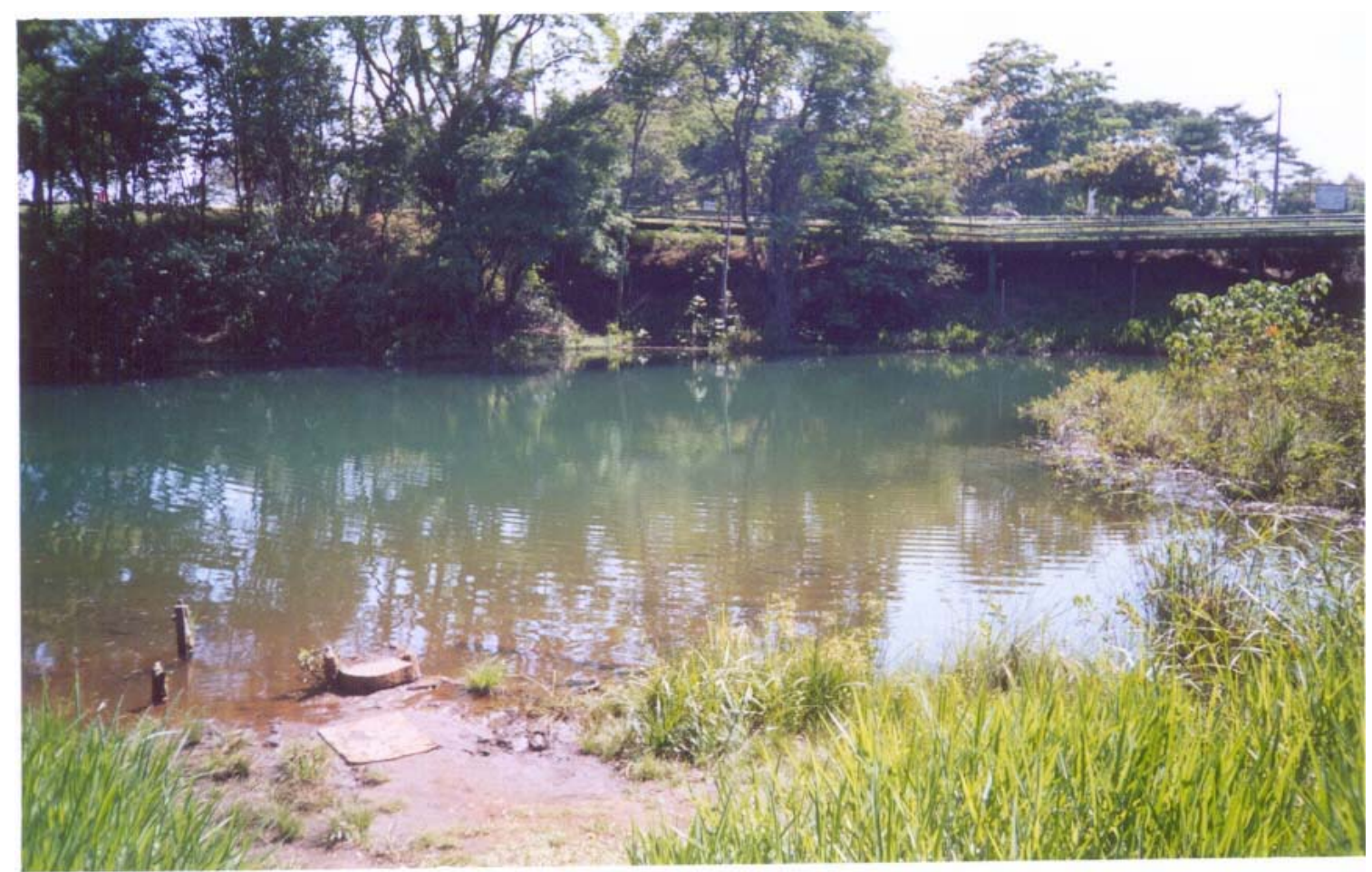

Figura 05: Lagoa do Sapo

Segundo Relatório Técnico n001/94, a limpeza do parque ficaria sob responsabilidade do Serviço de Limpeza Urbana (SLU). No parque existem lixeiras ao longo das trilhas as quais, segundo o administrador, são limpas pelos funcionários do parque. Apenas as lixeiras da entrada são destinadas a coleta seletiva, que periodicamente são recolhidos pelos caminhões da SLU. Foram realizadas diversas visitas no parque onde foi constatado que o lixo permanecia 
no local, as vezes por mais de 2 semanas, tornando-se foco para insetos e roedores.

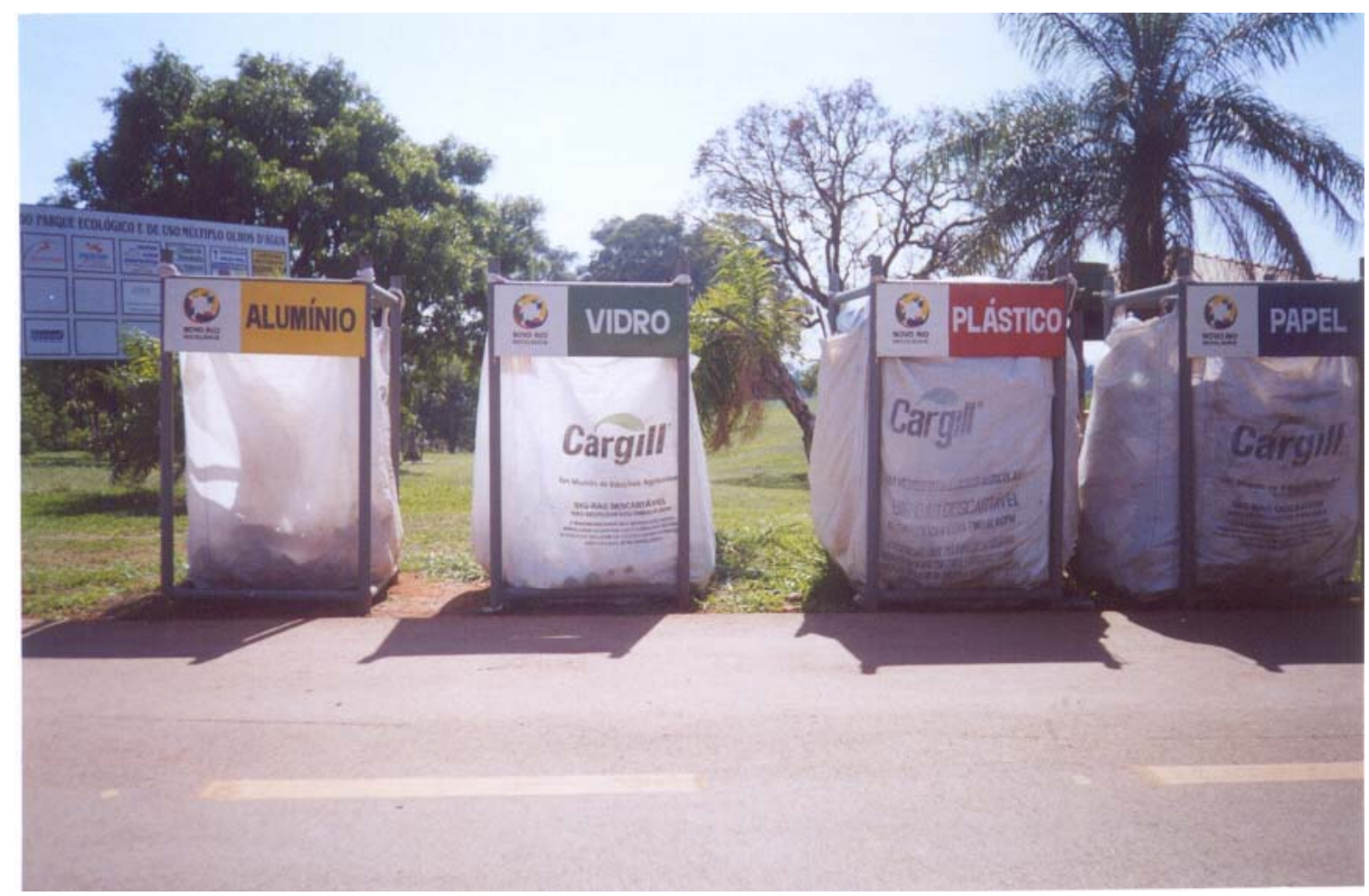

Figura 06: Vista das lixeiras para coleta seletiva

Foi observado a necessidade de padronização dos materiais trabalhados no parque como as lixeiras e as sinalizações. Segundo Ganem \& Leal (2000, p. 102) através de concessões a iniciativa privada poderão ser implantadas atividades isentas de causar danos ambientais. Com isso, poderiam ser realizadas benfeitorias no local como a própria sinalização. 


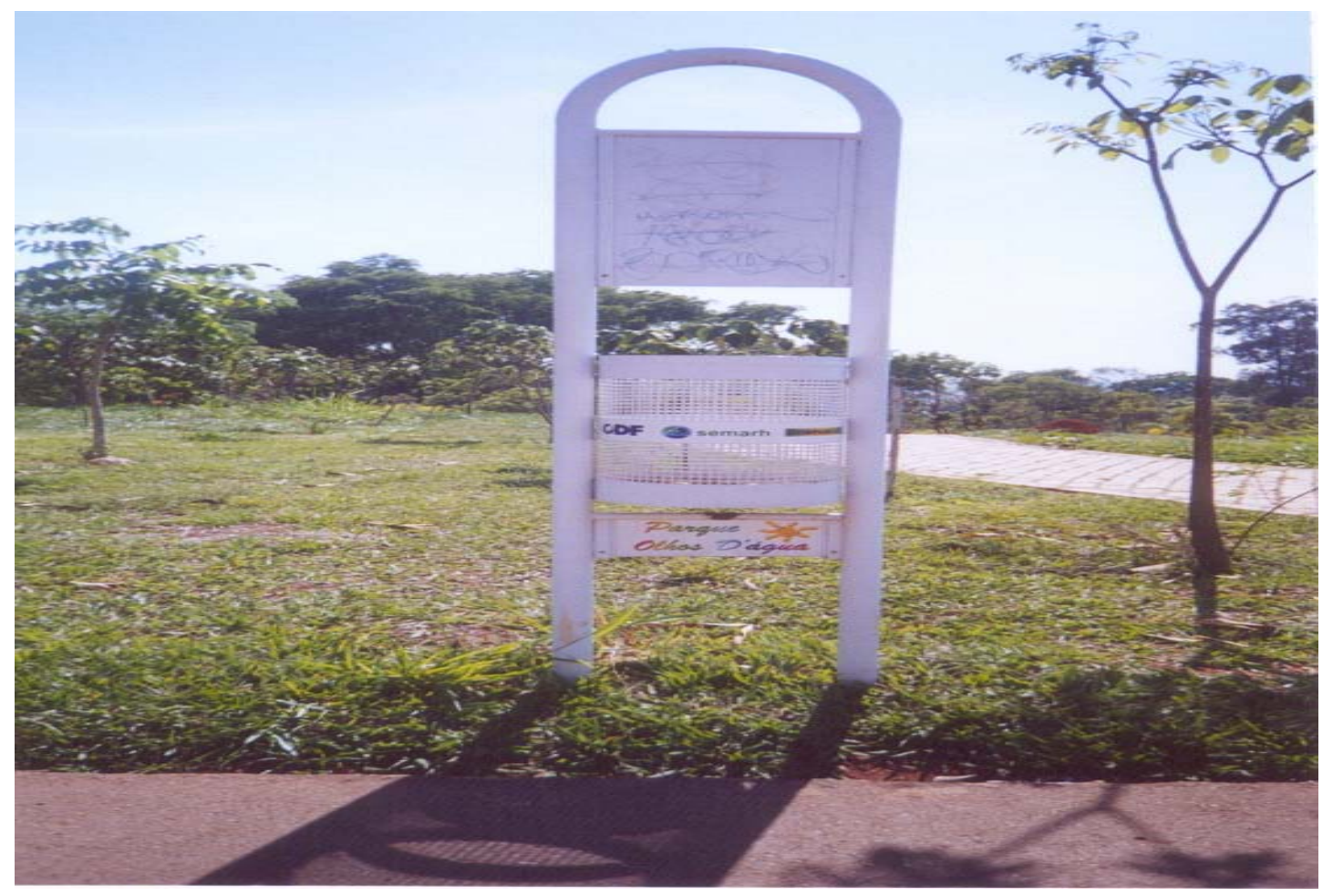

Figura 07: Modelo de lixeira existente ao longo da trilha

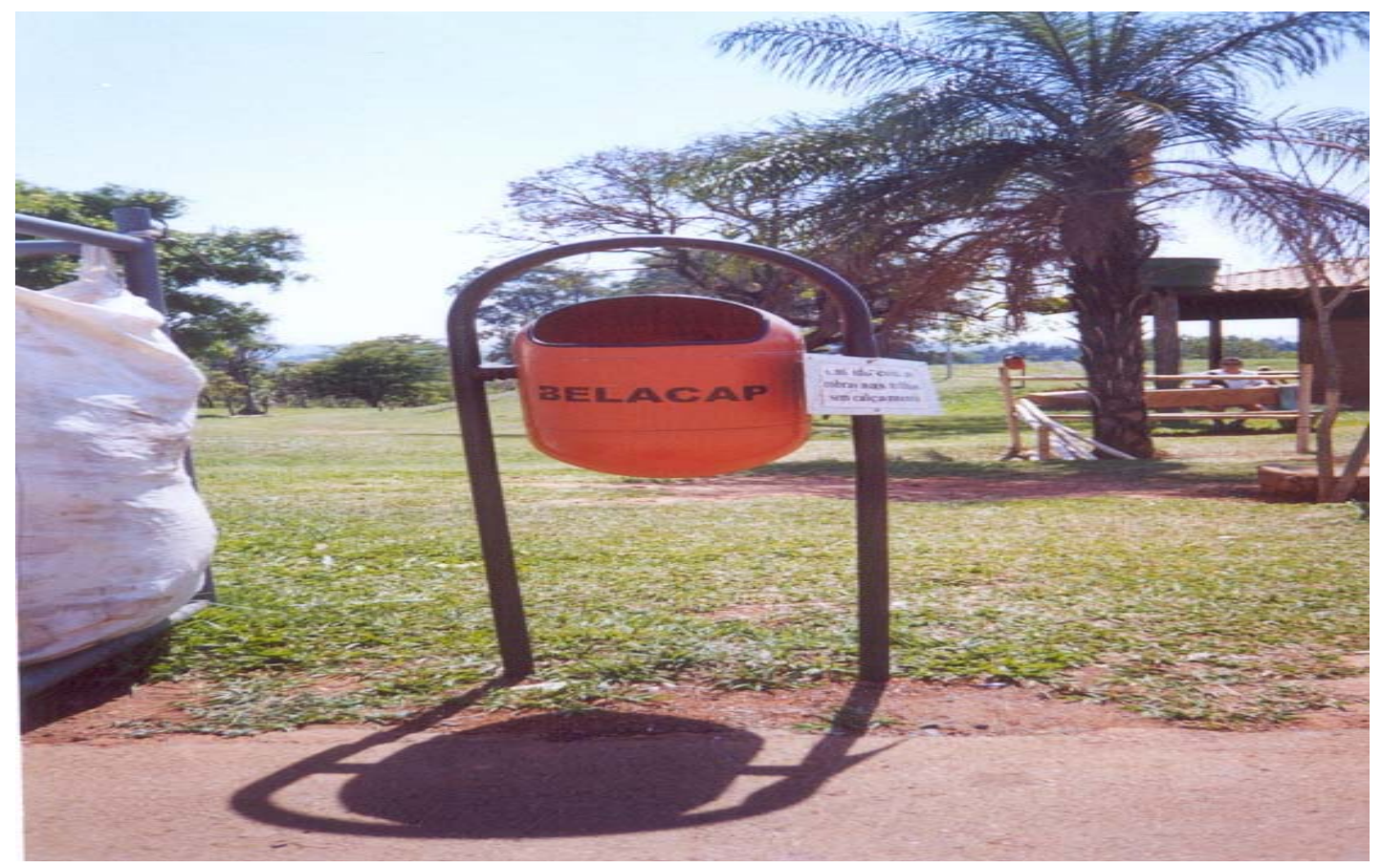

Figura 08: Modelo de lixeira existente na entrada do parque 
De acordo com o atual administrador, existe o interesse de que seja realizada uma padronização nas sinalizações ao longo de todo o parque. Hoje, muitas placas de advertência são precárias além de passarem por vandalismos. Abaixo, algumas fotos ilustram esse processo:

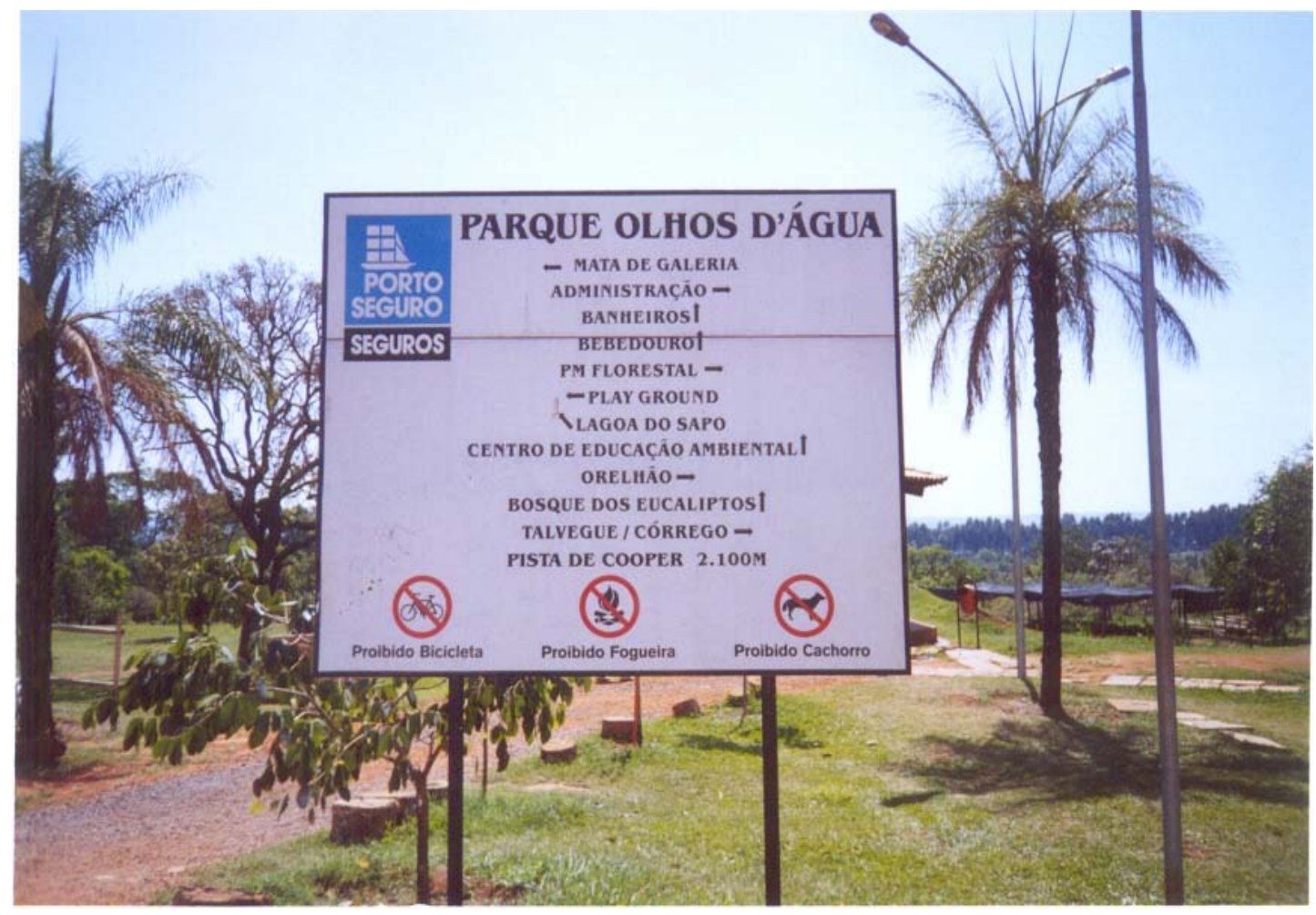

Figura 09: Placa existente para a localização dos atrativos turísticos do parque 


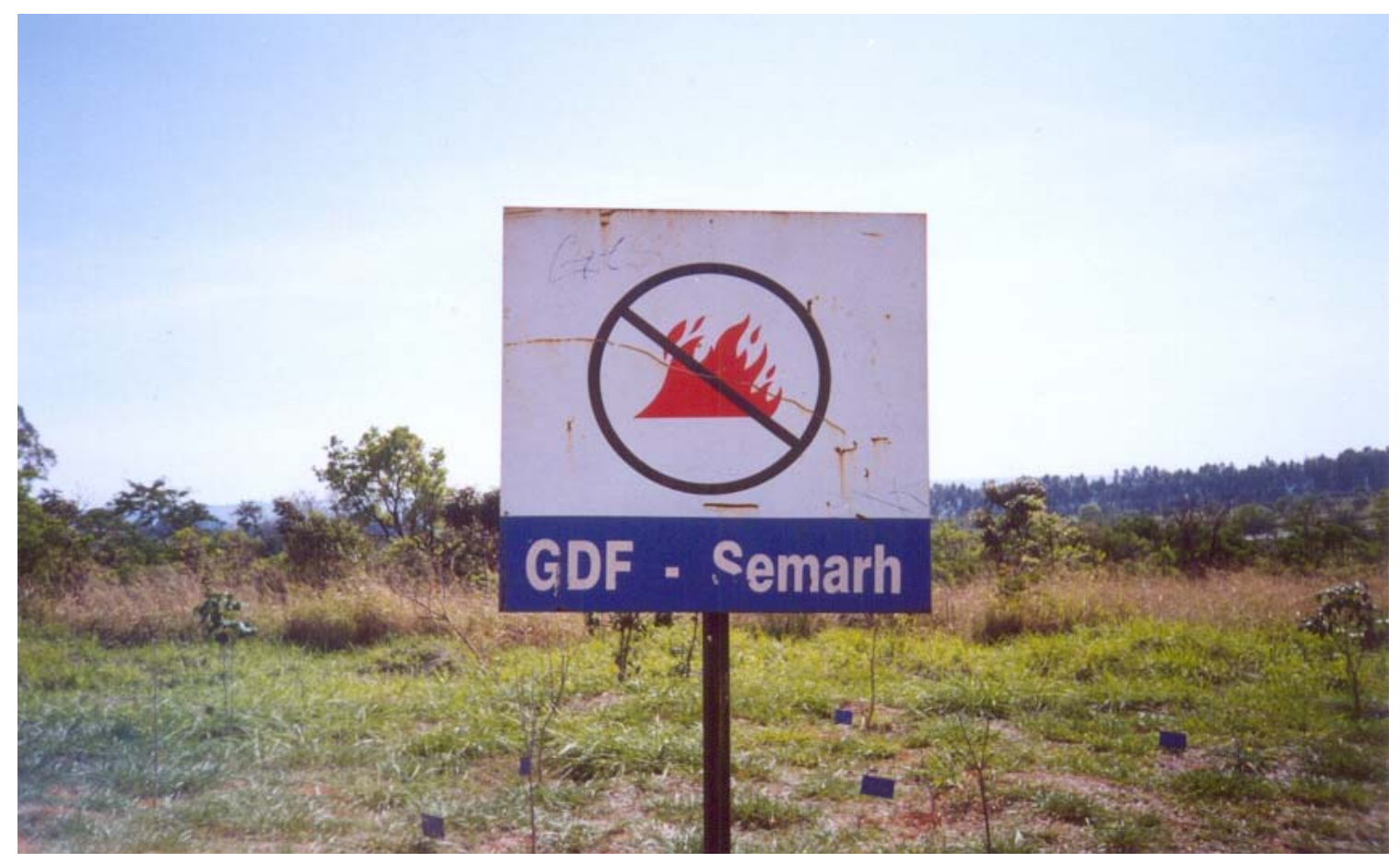

Figura 10: Sinalização contra atear fogo

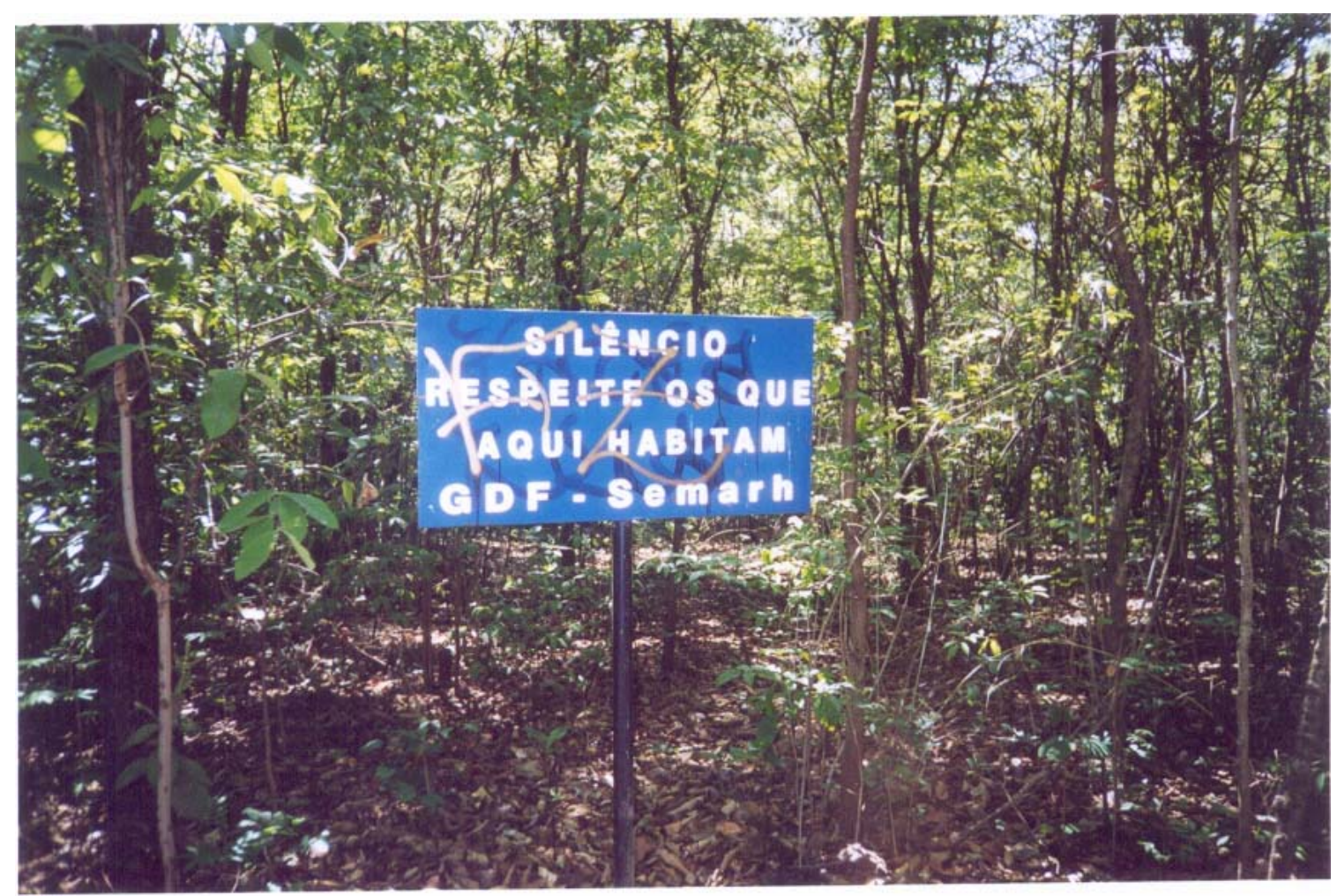

Figura 11: Placa danificada por ação de vandalismo 


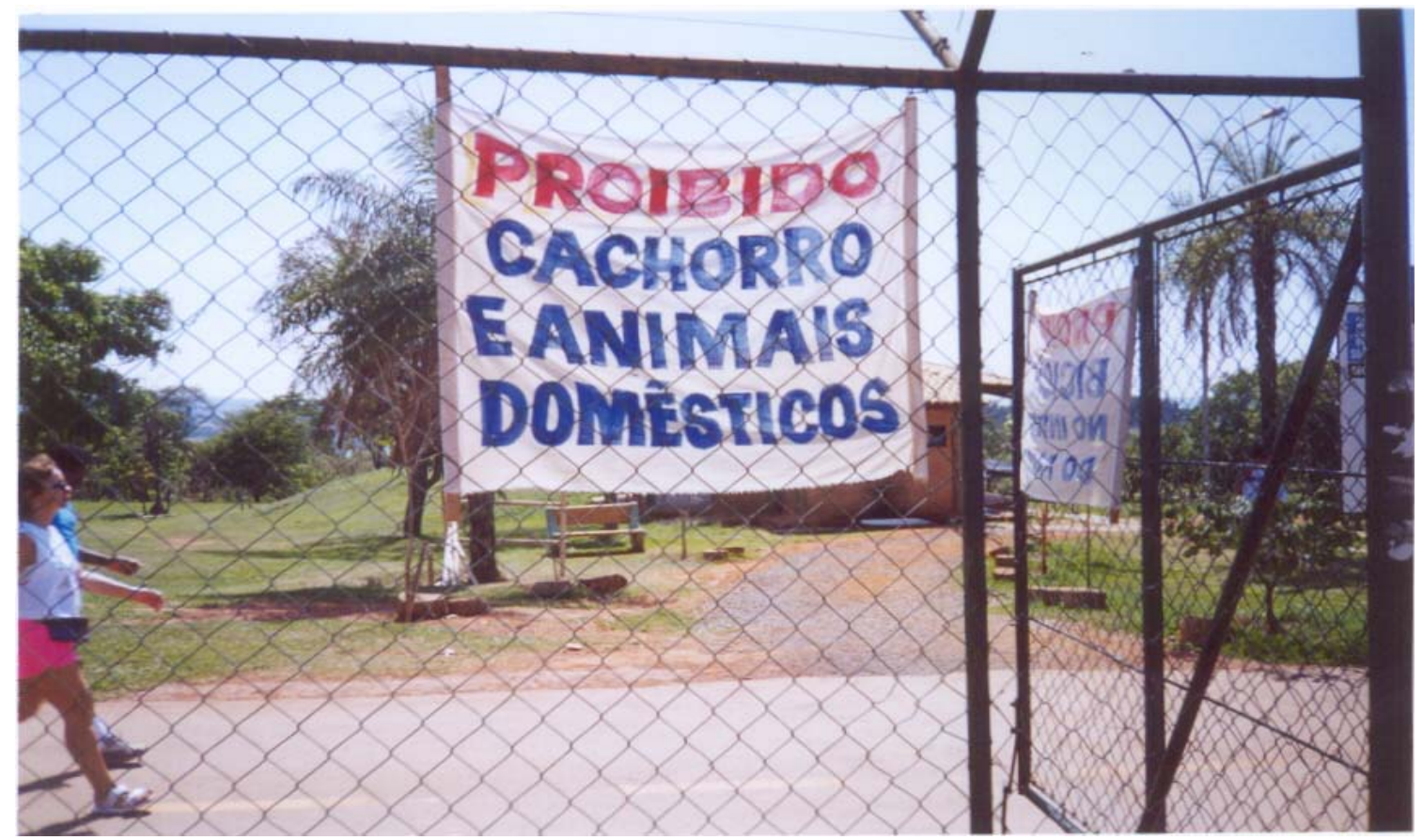

Figura 12: Placa informativa na entrada do parque

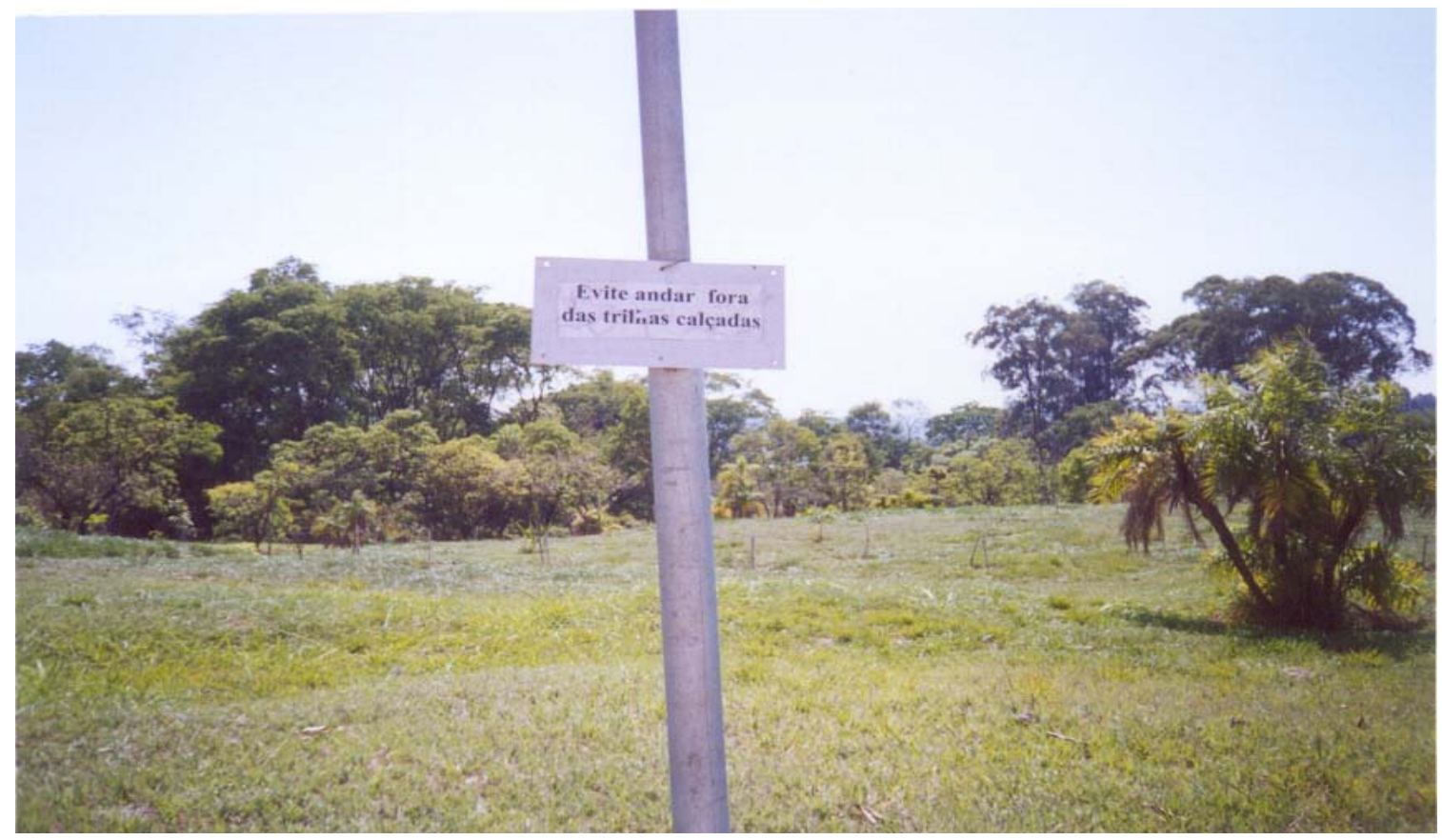

Figura 13: Aviso de alerta ao longo da trilha. 
Antes da criação do parque, esta área era formada por fazendas.

Fato este, que pode ser evidenciado até hoje devido a espécies de plantas exóticas.

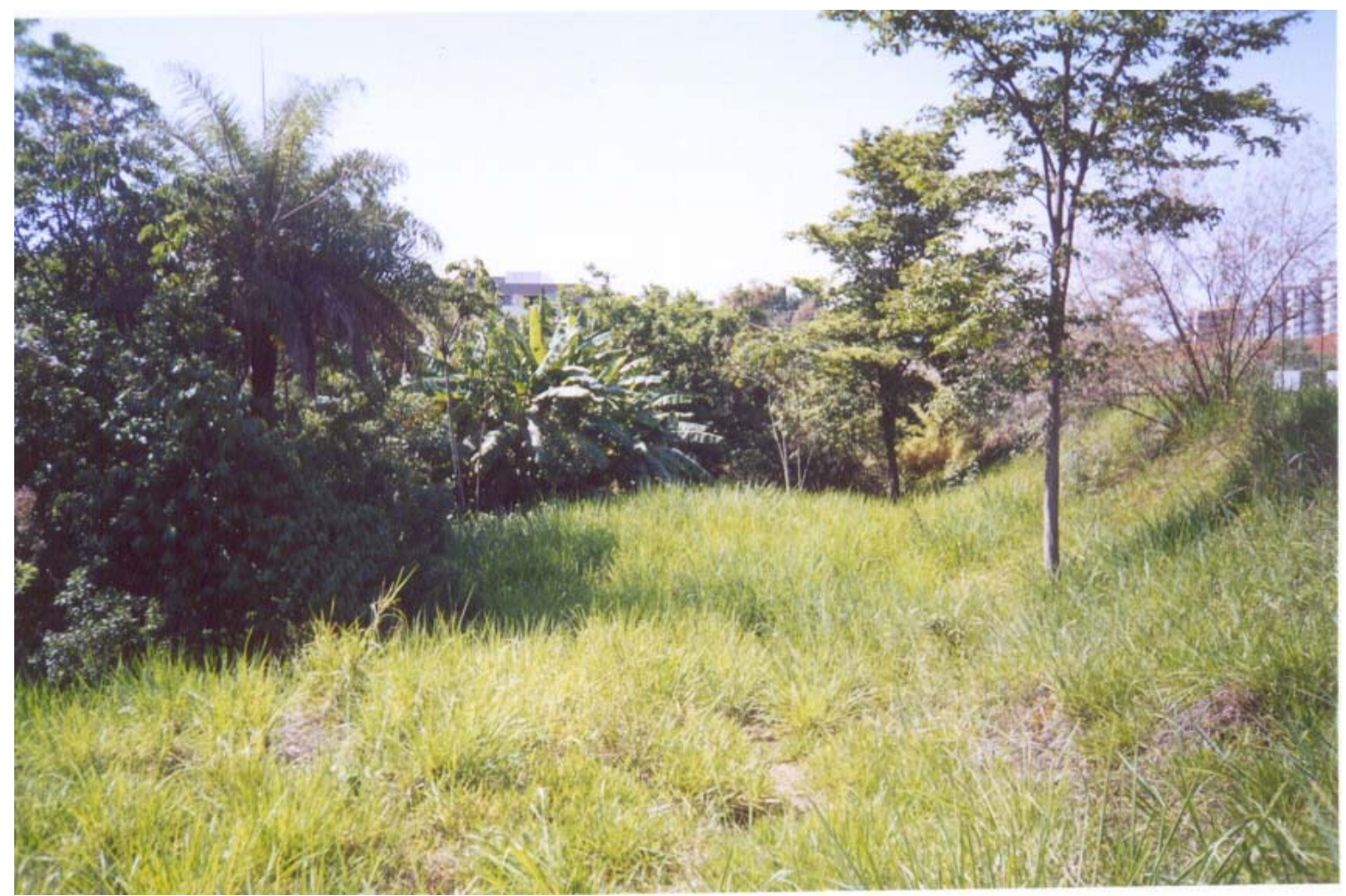

Figura 14: Espécies exóticas próximas as nascentes 


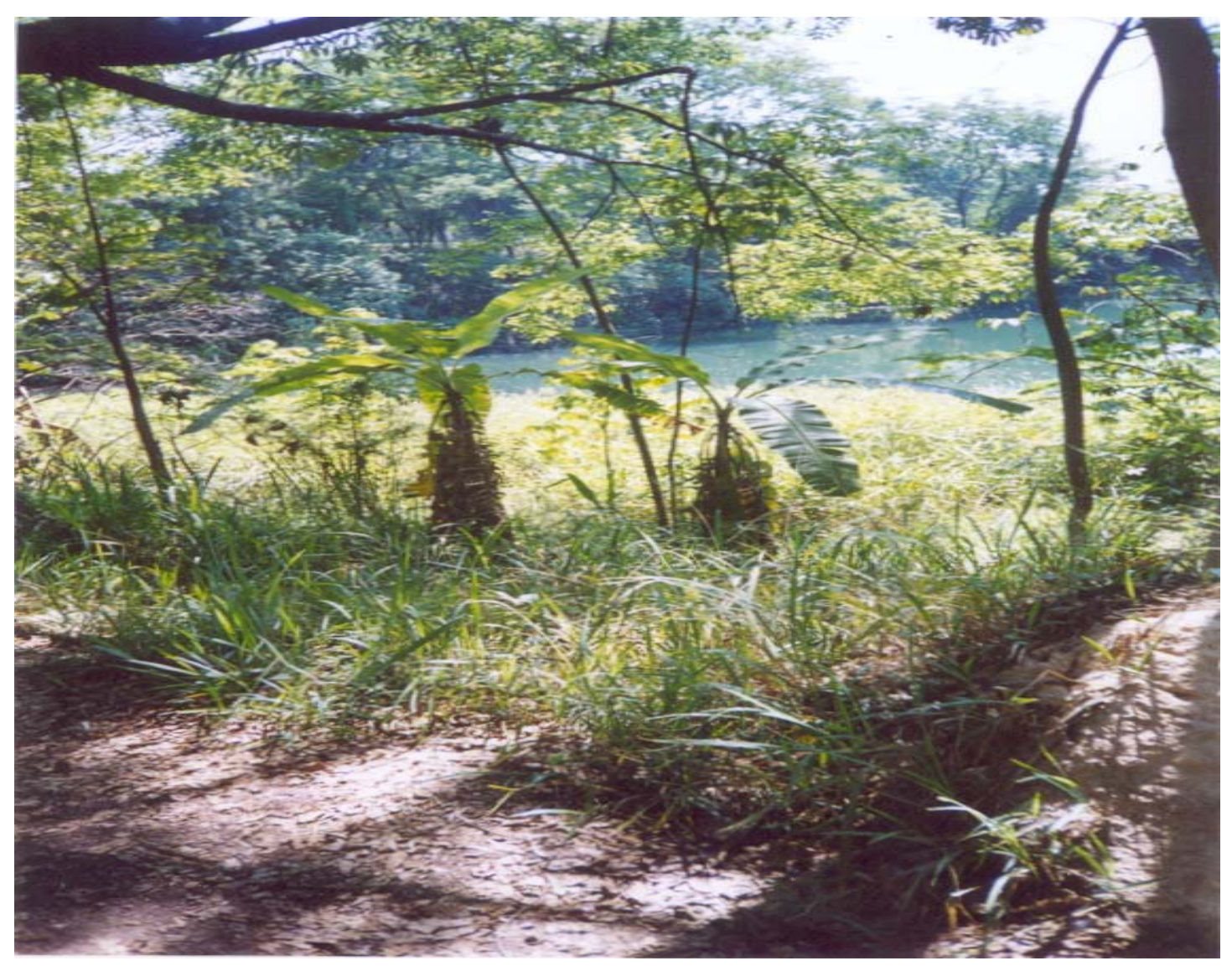

Figura 15: Presença de bananeiras próximo a Lagoa dos Sapos

O parque dispõe ainda de um parque infantil para os pais que visitam o parque com seus filhos; de equipamentos de ginástica, para aqueles visitantes que o procuram para a prática desportiva, além de lugares para a contemplação da natureza. 


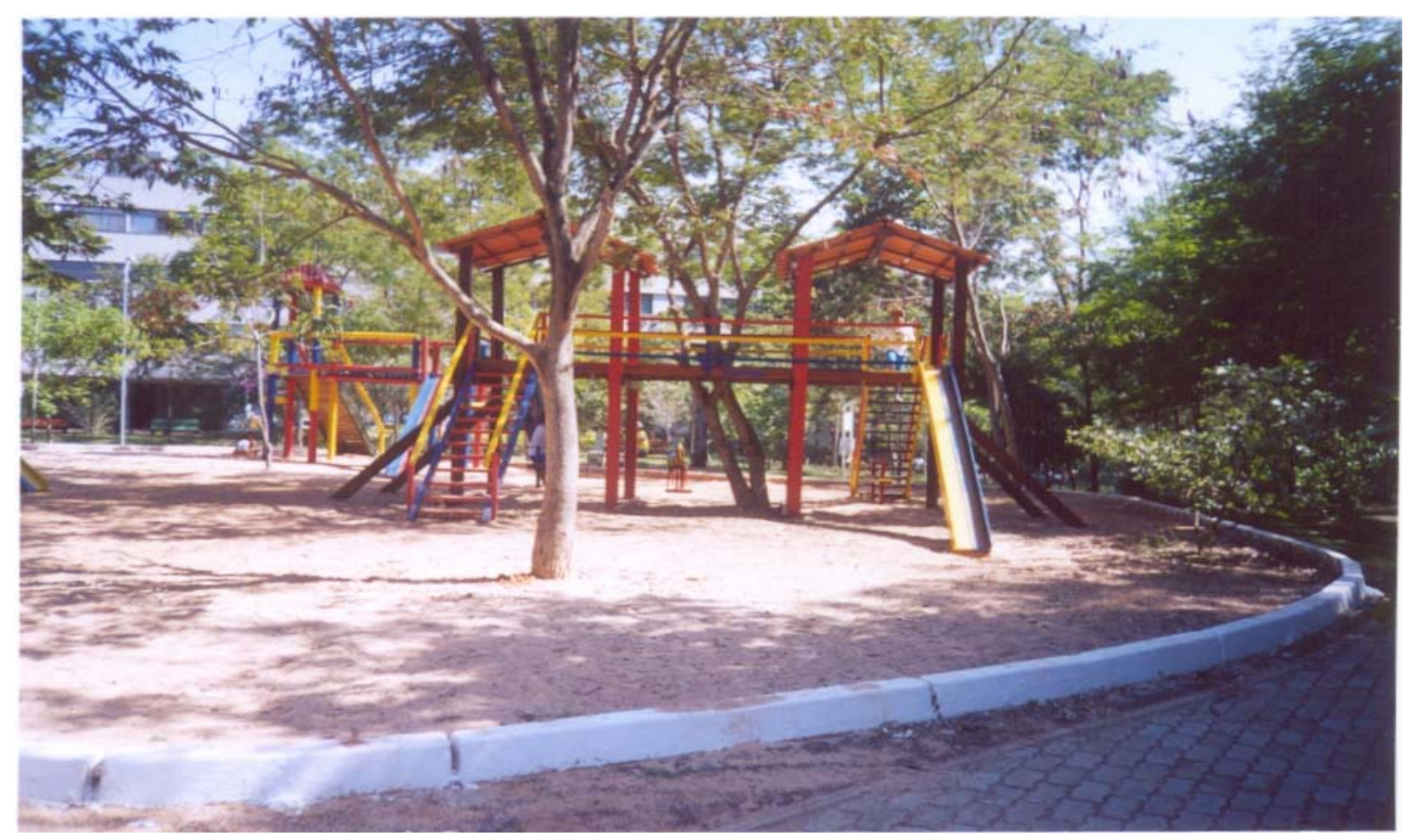

Figura 16: Parque Infantil

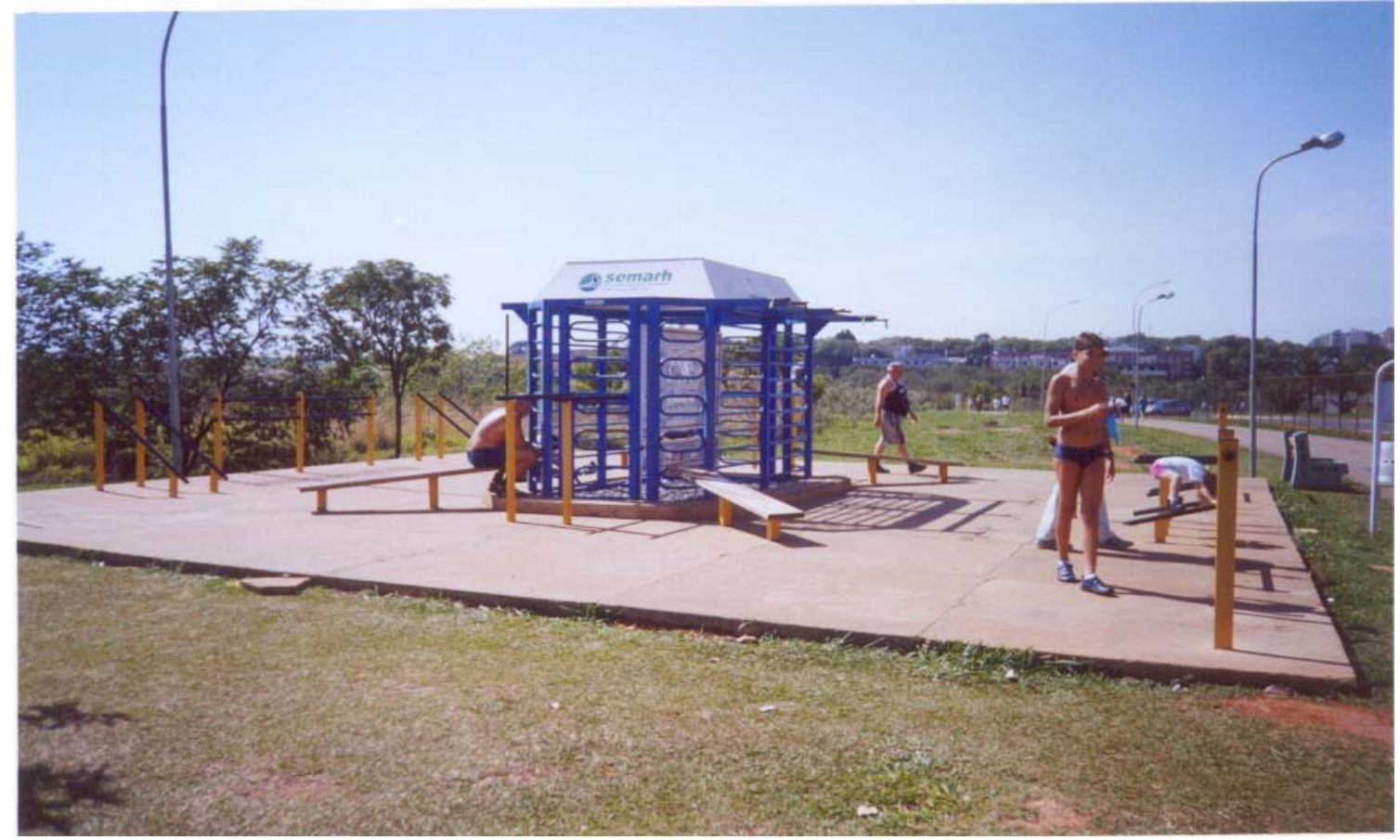

Figura 17: Equipamento de ginástica 


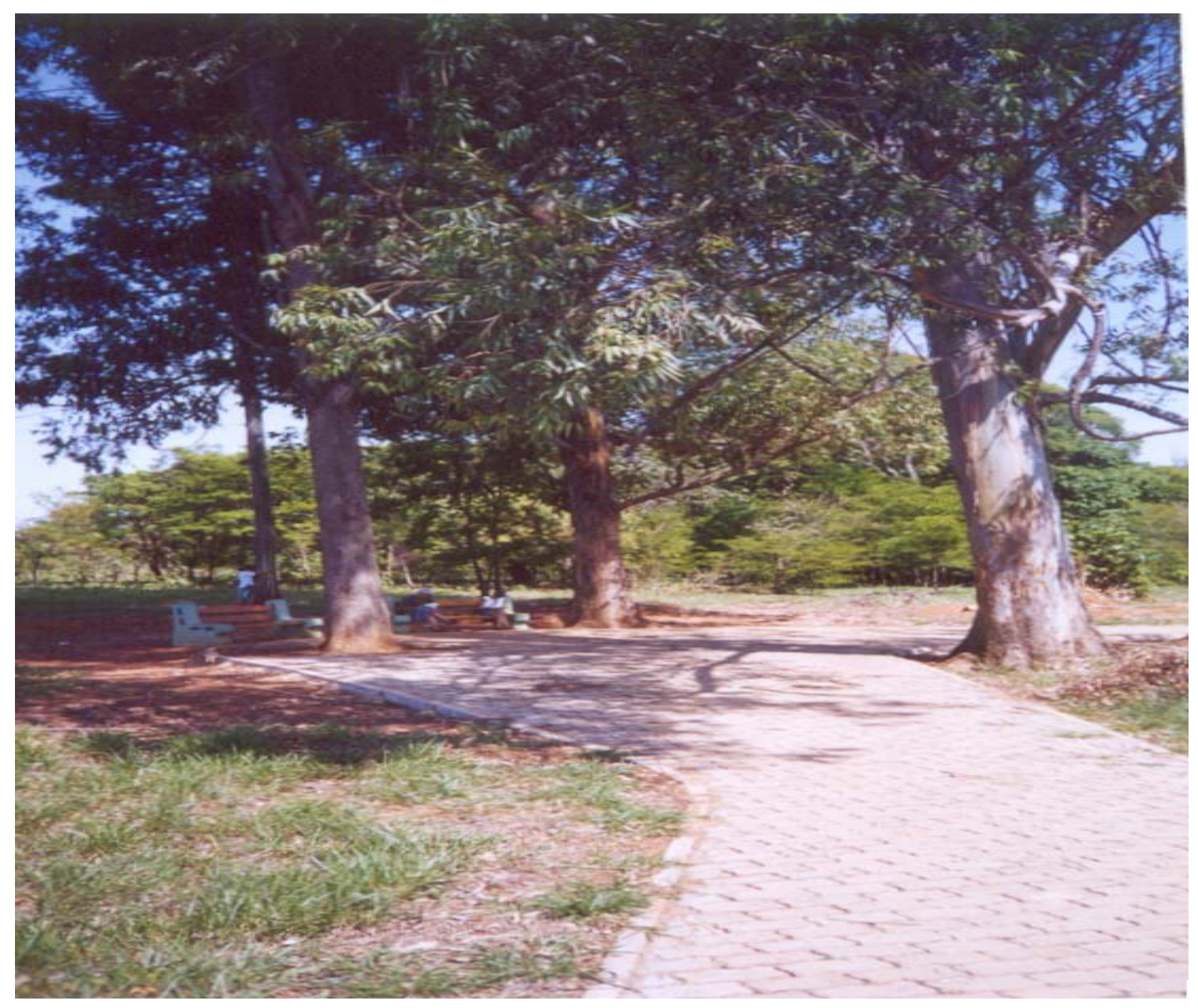

Figura 18: Bosque dos Eucaliptos (contemplação da natureza) 


\section{CONCLUSÃO}

Conclui-se que o estado de conservação do parque atualmente é bom, necessitando ainda de algumas melhorias. Estas melhorias puderam ser observadas durante as visitações realizadas

Ainda existem diversas medidas as serem tomadas uma delas é

realizar as modificações propostas no Plano de Zoneamento e Manejo da SEMARH. Esta adequação é de suma importância para minimizar ainda mais os problemas encontrados no local.

Deve-se realizar parcerias com a comunidade e a iniciativa privada, para atingir os propósitos de conservação e preservação das áreas naturais, proporcionando um aumento da consciência ecológica de toda a população que utiliza o parque.

Devem ser realizadas mais atividades de Educação Ambiental, não somente com escolas, mas sim com os próprios moradores que são os principais usuários do local. 
As barreiras governamentais devem ser diminuídas com o intuito de que melhorias sejam realizadas, assim como novas parcerias em estudos e levantamentos da área. 


\section{BIBLIOGRAFIA}

CÂMARA, J., B., D. \& SANTOS, T., C., C. Geo Brazil 2002 - Environmental Outlooks in Brazil. Brasília: IBAMA, 2002. 449p.

DECRETO N¹5.900 de 17 de SETEMBRO de 1994. Cria o Parque Olhos d’Água e dá outras providencias.

DECRETO N²1.784 de 05 de NOVEMBRO de 2000. Dispõe sobre o Regulamento Interno do Parque Ecológico e de Uso Múltiplo Olhos Dágua.

FARIA, D., S.; CARNEIRO, K., S. Sustentabilidade Ecológica no Turismo. Brasília: Universidade de Brasília, 2001. 95p.

FENNELL, D., A. Ecoturismo: uma introdução. São Paulo: Contexto, 2002. $281 p$. 
GANEM, R., S.; LEAL, Z., M. Parques do Distrito Federal. Câmara Legislativa do Distrito Federal, 2000. 127p.

LEI COMPLEMENTAR № 265, DE 14 DE DEZEMBRO DE 1999, Dispõe sobre a criação de Parques Ecológicos e de Uso Múltiplo no Distrito Federal.

MUNHOZ, T. Desenvolvimento sustentável e Educação Ambiental. http://www.intelecto.net/cidadania/meio-5.htm

NEVES, G., C., A . Ecoturismo: o caminho para o turismo responsável. Monografia apresentada ao Centro de Excelência em Turismo para a conclusão do curso de Gestão e Marketing do Turismo. Brasília, 2002. 49p.

PARQUE OLHOS DÁGUA. Exercício de um Plano de Zoneamento e Manejo. 1998, 40p.

$\begin{array}{lllll}\text { PIVELLO, } & \text { V., } & \text { R. } & \text { Cerrado. }\end{array}$ www.mre.gov.br/cdbrasil/itamaraty/web/port/meioamb/ecossit/cerrado/cabecal.htm

RELATÓRIO TÉCNICO N001/94 - GCA/DITEC/IEMA. Histórico das Ações no Parque Olhos d’água.

RIBEIRO, J., F.; ALMEIDA, S., P.; BARROS, C., J., S. Conservação e Manejo da Biodiversidade do Cerrado: Potencialidades e ameaças à vegetação nativa. 
http://sbpcnet.org.br/eventos/54ra/TEXTOS/SBPC/SBPC $\% 20 \mathrm{~J} \% 20$ Felipe $\% 20 \%$ Ri $\underline{b} .$.

SALVATI, S., S. Ecoturismo no Pantanal Brasileiro e Boliviano: estudo de políticas e alternativas sustentáveis. Dissertação de mestrado. Programa de pós-graduação em Integração da América Latina, Universidade de São Paulo. 2002.

SEMARH,Secretaria De Estado de Meio Ambiente e Recursos Hídricos do Distrito Federal. Das políticas, Das Ações E Dos Projetos. 2003, 140p. 